\title{
Ocena czynników ryzyka występowania bólów okolicy lędźwiowo-krzyżowej u nastolatków w wieku 11-14 lat
}

\section{The assessment of risk factors of low back pain in adolescents between 11-14 years old}

\author{
Ewa Lenart-Domka ${ }^{1,2}$, Anna Świerad ${ }^{2}$ \\ ${ }^{1}$ Regionalny Ośrodek Rehabilitacyjno-Edukacyjny Szpitala Wojewódzkiego Nr 2, \\ Rzeszów \\ ${ }^{2}$ Instytut Fizjoterapii Uniwersytetu Rzeszowskiego, Rzeszów
}

\section{Streszczenie}

Wstęp: Bóle okolicy lędźwiowo-krzyżowej (L-S) w wieku rozwojowym do niedawna traktowane były jako marginalny problem zdrowotny. Coraz częściej jednak zwraca się uwagę, że nawet epizodyczne dolegliwości tej okolicy u młodych osób stanowią wyraźną predyspozycję do ich występowania w przyszłości. Scharakteryzowanie modyfikowalnych czynników ryzyka może przyczynić się do ograniczenia częstości występowania tego problemu w życiu dorosłym.

Cel pracy: Ocena częstości występowania i czynników ryzyka bólów okolicy L-S u nastolatków w wieku 11-14 lat w zależności od uwarunkowań środowiskowych, stylu życia oraz czynników psychicznych.

Materiat i metody: Na podstawie ankiety własnej oraz Kwestionariusza Mocnych Stron i Trudności Goodmana przeprowadzonych wśród 207 dzieci w wieku 11-14 lat z powiatów rzeszowskiego i strzyżowskiego poszukiwano związku występowania bólu okolicy L-S ze statusem ekonomicznym rodziny, sposobem przemieszczania się do szkoły, ciężarem teczki szkolnej, obciążeniami pracą fizyczną po szkole, formami spędzania czasu wolnego, poziomem codziennej aktywności fizycznej oraz stanem psychicznym badanych.

Wyniki: Bóle okolicy L-S zgłosiło 32,9\% uczniów. Występowały one bez związku z płcią, poziomem zamożności rodziny czy sposobem przemieszczania się do szkoły. Przeważały u dzieci z rejonów wiejskich wykonujących prace fizyczne po szkole. Istotny związek z bólami kręgosłupa L-S w tym wieku ma nadmierny ciężar teczki szkolnej, siedzący tryb życia, intensywne uprawianie sportu, a także trudnościami psychicznymi: zaburzenia emocji, zachowania, trudności w komunikacji z rówieśnikami oraz nadaktywność i zaburzenia koncentracji uwagi.

Wnioski: Wśród czynników ryzyka bólów okolicy L-S w wieku młodzieńczym dominuje zarówno statyczne jak i dynamiczne przeciążenie kręgosłupa, dolegliwości częściej występują u dzieci z problemami psychicznymi.

Słowa kluczowe: ból kręgosłupa lędźwiowo-krzyżowego (L-S), nastolatki, czynniki ryzyka 


\section{Abstract}

Introduction: Until recently low back pain (LBP) in adolescents has been treated like a minor health problem. It becomes more remarkable lately that even short LBP episodes in adolescents are strongly prognostic of this problem in adulthood. Finding univocal modifiable LBP prognostic indicators may contribute to reduce its prevalence in the future.

The objective of the study: To show the prevalence and risk factors of low back pain in children aged 11-14 regarding environmental determinants, life style and psychological problems.

Material and methods: A self-reported questionnaire survey and polish version of Strengths and difficulties questionnaire (SDQ-Pol) was provided in 207 children aged 11-14 attending schools in Rzeszów and Strzyżów district in order to find the relationship mainly between LBP and family economic status, ways of school displacement, weight of school bag, physical work after school, ways of spending free time, sports activities and psychological problems.

Results: Low back pain was reported by $32,9 \%$ pupils. Gender, family economic status or school displacement manner did not affect LBP prevalence. LBP occurred more often in rural area, especially when children did physical work after school. Other risk factors were excessive spine mechanical burden, sedentary way of living, intensive sports and psychological difficulties: mostly emotional and interpersonal communication disturbances, hyperactivity and behavioral problems.

Conclusions: Static and dynamic spine overburdening is the most often occurring risk factors of LBP in adolescents as well as psychological problems.

Key words:

low back pain (LBP), adolescents, risk factors

\section{Wstęp}

Dolegliwości bólowe okolicy lędźwiowo-krzyżowej kręgosłupa (L-S) u dzieci i nastolatków stanowią coraz większy problem medycyny wieku rozwojowego [1]. Najczęściej są to dolegliwości o niespecyficznym charakterze, bez wyraźnego podłoża organicznego. Rzadziej występują specyficzne zespoły bólowe związane z miejscową patologią struktur kręgosłupa, których przyczyną mogą być urazy i ich następstwa (złamania kręgów, kręgozmyk, choroba dyskowa), wady rozwojowe kręgosłupa i rdzenia kręgowego, zmiany degeneracyjne krążka międzykręgowego, procesy zapalne o podłożu infekcyjnym i immunologicznym (zapalenie krążka międzykręgowego, ropnie wewnątrzkanałowe, neuroborelioza, młodzieńcze idiopatyczne zapalenie stawów, łuszczyca, początkowe objawy zapalenia rdzenia kręgowego czy choroby Guillain-Barre), zmiany naczyniopochodne (choroba Scheuermanna), nowotwory pierwotne i przerzutowe. Bóle kręgosłupa mogą być również spowodowane chorobami ogólnoustrojowymi takimi jak osteoporoza, osteomalacja, choroba Pageta, cukrzyca, a także schorzeniami sąsiadujących narządów wewnętrznych, toczącymi się głównie w układzie pokarmowym i moczowo-płciowym (przewlekłe choroby wątroby, jelit, nerek) $[2,3,4,5]$. Podobnie jak u dorosłych, zdarzają się również dolegliwości na podłożu psychogennym $[6,7]$.
Przez wiele lat bóle kręgosłupa w wieku młodzieńczym traktowane były jako marginalny problem zdrowotny. Po raz pierwszy zainteresował się nim pod koniec XX wieku fiński lekarz J. J. Salminen [8]. Od tej pory próbuje się ocenić skalę tego zjawiska w różnych populacjach i scharakteryzować w sposób jednoznaczny czynniki ryzyka mogące wpływać na ich wystąpienie. Nie jest to zadanie łatwe, ponieważ najczęściej mamy do czynienia z zespołami bólowymi o wieloczynnikowych uwarunkowaniach. Największą uwagę obecnie zwraca się na ustalenie czynników modyfikowalnych, zależnych od stylu życia, poziomu aktywności ruchowej, sposobów funkcjonowania emocjonalnego i społecznego[1]. Coraz częściej pisze się o tym, że nawet epizodycznie występujące bóle odkręgosłupowe w młodym wieku stanowią wyraźną predyspozycję do występowania tego typu dolegliwości w wieku dorosłym, zwłaszcza jeśli współistnieją problemy psychiczne pod postacią zaburzeń społeczno-emocjonalnych i behawioralnych. Prognozują one nawracający i przewlekły przebieg dolegliwości w życiu dorosłym $[6,7,9]$.

Celem pracy była ocena częstości występowania bólów okolicy lędźwiowo-krzyżowej u dzieci szkolnych w wieku 11-14 lat w zależności od uwarunkowań środowiskowych, stylu życia i czynników psychicznych. 


\section{Materiał i metody}

Po uzyskaniu zgody komisji etycznej działającej przy Uniwersytecie Rzeszowskim (nr 10/03/2008) do badania zakwalifikowano, po uwzględnieniu wymienionych niżej kryteriów wyłączenia, 207 dzieci w wieku 11-14 lat ze szkół podstawowych i gimnazjalnych z powiatu rzeszowskiego i strzyżowskiego na Podkarpaciu (dobór szkół losowy, typ randomizacji prosty). Jako narzędzia badawczego użyto ankiety własnej wypełnianej anonimowo przez uczniów w obecności jednej z autorek. W części pierwszej zbierano dane demograficzno-środowiskowe: płeć, miejsce zamieszkania, wykształcenie rodziców, status materialny rodziny, sposób przemieszczania się do szkoły. Przeprowadzono subiektywną ocenę statusu materialnego rodziny, nastolatki odpowiadały na pytanie" Czy Twoja rodzina jest bogata?" z możliwymi odpowiedziami: „,bardzo biedna” , „raczej biedna”, „,bardzo bogata” i „raczej bogata”, ,przeciętna”. W drugiej części dzieci odpowiadały na pytania dotyczące częstości występowania bólu w ostatnim miesiącu poprzedzającym badanie, sposobach radzenia sobie z bólem, związku bólu z krwawieniem miesięcznym. W trzeciej części pytano o sposoby spędzania czasu wolnego: ile godzin dziennie dziecko spędza przed telewizorem i komputerem, czy i ile czasu tygodniowo poświęcają na uprawianie sportu oraz wykonywanie pracy fizycznej w czasie wolnym. Opiekunów dzieci poproszono o codzienne ważenie teczki szkolnej przez pięć kolejnych dni i zapisanie wyniku w dzienniczku. Następnie obliczono średnią arytmetyczną pięciu pomiarów z jednego tygodnia szkolnego. Ankietę wcześniej przetestowano pod kątem powtarzalności odpowiedzi w odstępie dwutygodniowym w grupie 30 uczniów w analogicznym wieku. Opiekunowie uczniów otrzymali do wypełnienia polską wersję Kwestionariusza o Stronach Mocnych i Trudnościach Goodmana (Goodman's Strengths and Difficulties Questionnaire, SDQ - pol) opracowaną przez Roberta Goodmana w 1997 roku, walidowaną przez następujących autorów: B. Davey, J. Cieciuch, M. Maćkiewicz, M. Najderska, I. Skoczeń $[10,11]$. Polska wersja tego kwestionariusza jest dostępna do celów badawczych za pośrednictwem organizacji Youth in mind zwalczającej stres dzieci i młodzieży oraz promującej metody osiągnięcia dobrostanu psychicznego w tej grupie wiekowej [11]. W Polsce kwestionariusz ten został zastosowany w latach 2007 i 2008 w badaniach epidemiologicznych oceniających jakość życia młodzieży z populacji ogólnej ustalając w ten sposób polskie normy [12,13]. Składa się on z czterech podskal służących do oceny funkcjonowania psychicznego dziecka: zaburzenia emocji, zachowania, nadaktywność i zaburzenia koncentracji uwagi, problemy w kontaktach $\mathrm{z}$ rówieśnikami. $\mathrm{W}$ każdym pytaniu możliwe były trzy warianty odpowiedzi: całkiem prawda, częściowo praw- da i nieprawda. Odpowiedzi punktowane były od 0 do 2 punktów dla stwierdzeń negatywnych i od 2 do 0 punktów dla stwierdzeń pozytywnych. Wynik ogólny mógł wynosić od 0 do 40 punktów. Wysoka liczba punktów wiąże się ze wzrostem nasilenia trudności psychiczno-społecznych. Zgodnie z przyjętymi kryteriami oceny wynik końcowy osiągnięty w kwestionariuszu SDQ może być: w normie (0-15 punktów), na granicy normy (16-19 punktów), poniżej normy (20-40 punktów). Kryteriami włączenia do programu były: wiek dziecka 1114 lat, pisemna zgoda rodziców na udział w programie. Kryteriami wyłączenia z programu były: wiek poniżej 11 i powyżej 14 lat, stwierdzenie współistnienia bólu okolicy L-S kręgosłupa z krwawieniem miesięcznym, brak kompletnego dzienniczka pomiarów ciężaru plecaka szkolnego, brak zgody rodziców, niekompletne wypełnienie ankiety lub kwestionariusza SDQ. Odrzucono 42 ankiety, ostatecznie włączono 207 uczniów, w tym 118 dziewcząt i 89 chłopców. Do analizy statystycznej użyto nieparametrycznego testu niezależności chi-kwadrat. Za poziom istotności przyjęto $\mathrm{p}<0,05$. Do oceny wiarygodności zastosowanego kwestionariusza użyto metody powtarzanego pomiaru (ang. test retest method) przyjmując zgodnie z ogólnie uznanymi kryteriami powtarzalności testów poziom rzetelności przy $r_{t t} \geq 0,80$ [14]. Analiza powtórnego pomiaru zastosowanego kwestionariusza wyżej wymienioną metodą pozwala uznać ją za rzetelną $\left(\mathrm{r}_{\mathrm{tt}}=0,86\right)$.

\section{Wyniki}

Występowanie bólu okolicy L-S w ciągu poprzedzającego miesiąca stwierdzono u co trzeciego ankietowanego dziecka (69 osób, 32,9\%). U 45 uczniów (21,7\%) ból trwał dłużej niż jeden dzień. U większości dolegliwości ustąpiły samoistnie, tylko jedno dziecko korzystało z tego powodu z porady lekarskiej. Wprawdzie ból częściej zgłaszały dziewczynki, nie była to jednak zależność istotna statystycznie. Nie stwierdzono również, aby poziom zasobności rodziny czy wykształcenie rodziców miały związek z występowaniem dolegliwości bólowych kręgosłupa. Istotnie częściej natomiast zgłaszały je dzieci mieszkające na wsi. Bóle okolicy L-S zgłaszało $20 \%$ dzieci mieszkających w mieście oraz 36\% dzieci mieszkających na terenach wiejskich $(\mathrm{p}=0,038)$. Sposób dojazdu dzieci do szkoły nie miał wpływu na pojawianie się bólu w przeciwieństwie do ciężaru plecaka czy teczki szkolnej. Książki i przybory noszone codziennie do szkoły przez 106 uczniów (51\%) ważyły 6 - $7 \mathrm{~kg}$, u 47 dzieci $(22,7 \%)$ teczka była cięższa niż $7 \mathrm{~kg}$. Im więcej ważył plecak, tym częściej występowały bóle okolicy kręgosłupa L-S. Wykazywały one wyraźną tendencję wzrostową przy ciężarze plecaka większym lub równym $8 \mathrm{~kg}$ (p $<0,001)$. 
Tab. 1. Ciężar teczki/plecaka a występowanie bólu kręgosłupa L-S $(p<0,001)$

Tab. 1.The schoolbag weight and the prevalence of LBP

\begin{tabular}{|c|c|c|c|c|c|c|c|c|c|c|}
\hline \multirow{2}{*}{ Liczba dzieci } & \multicolumn{7}{|c|}{ Ciężar plecaka (kg) } & \multirow{2}{*}{ ogółem } \\
\cline { 2 - 10 } & $3-5$ & 4 & 5 & 6 & 7 & 8 & 9 & $>10$ & \\
\hline $\begin{array}{c}\text { z bólem kręgosłupa } \\
\text { L-S }\end{array}$ & $9(50 \%)$ & $3(23 \%)$ & $2(6 \%)$ & $5(7 \%)$ & $10(29 \%)$ & $17(94 \%)$ & $19(90 \%)$ & $8(100 \%)$ & 68 \\
\hline $\begin{array}{c}\text { bez bólu kręgosłupa } \\
\text { L-S }\end{array}$ & $4(50 \%)$ & $10(77 \%)$ & $31(94 \%)$ & $67(93 \%)$ & $24(71 \%)$ & $1(6 \%)$ & $2(10 \%)$ & $0(0 \%)$ & 139 \\
\hline ogółem & 8 & 13 & 33 & 72 & 34 & 18 & 21 & 8 & 207 \\
\hline
\end{tabular}

Wpływ stylu życia na występowanie dolegliwości bólowych kręgosłupa L-S

Oceniając formy spędzania czasu wolnego stwierdzono, że u badanych dzieci dominują rozrywki o charakterze biernym. Uczniowie, dla których podstawową formą aktywności powinien być ruch, znaczną część dnia spędzają w pozycji siedzącej. Prawie $75 \%$ badanych (154 osoby) przyznaje się do spędzania przed komputerem od jednej do dwóch godzin dziennie.

Tab. 2. Czas spędzany dziennie przed komputerem i telewizorem

Tab. 2. The amount of time spent daily on PC activities and TV watching

\begin{tabular}{|c|c|c|}
\hline Czas & $\begin{array}{c}\text { Liczba dzieci spędzających czas przed } \\
\text { komputerem }\end{array}$ & $\begin{array}{c}\text { Liczba dzieci spędzających czas przed } \\
\text { telewizorem }\end{array}$ \\
\hline $0 \mathrm{~h}$ & $7(3,4 \%)$ & 0 \\
\hline $\mathrm{h}$ & $69(33,3 \%)$ & $29(14,0 \%)$ \\
\hline $2 \mathrm{~h}$ & $85(41,1 \%)$ & $74(35,7 \%)$ \\
\hline $3 \mathrm{~h}$ & $24(11,6 \%)$ & $75(36,2 \%)$ \\
\hline $4 \mathrm{~h}$ i więcej & $22(10,6 \%)$ & $29(14,0 \%)$ \\
\hline
\end{tabular}

Podobnie wysoki odsetek ankietowanych dzieci (149 osób, 71,9\%) spędza przed telewizorem od 2 do 3 godzin dziennie, 14\% dzieci (29 osób) przeznacza dziennie
4 godziny i więcej na oglądanie telewizji. Równocześnie 130 badanych (62 \%) przeznacza na pozalekcyjne zajęcia sportowe mniej niż godzinę dziennie.

Tab. 3. Czas tygodniowo przeznaczany na sport

Tab. 3. The amount of time scheduled weekly for sports activities

\begin{tabular}{|c|c|c|}
\hline Czas tygodniowo przeznaczany na sport & Liczność & odsetek \\
\hline $2-3 \mathrm{~h}$ & 44 & $21,3 \%$ \\
\hline $4-5 \mathrm{~h}$ & 86 & $41,5 \%$ \\
\hline $6-7 \mathrm{~h}$ & 50 & $24,2 \%$ \\
\hline $8-9 \mathrm{~h}$ & 14 & $6,8 \%$ \\
\hline $10-11 \mathrm{~h}$ & 5 & $2,4 \%$ \\
\hline $12-13 \mathrm{~h}$ & 2 & $1,0 \%$ \\
\hline $14-15 \mathrm{~h}$ & 3 & $1,4 \%$ \\
\hline $16-17 \mathrm{~h}$ & 3 & $1,4 \%$ \\
\hline
\end{tabular}

W analizie statystycznej widać dodatnią korelację między ilością czasu spędzaną przed komputerem czy telewizorem a występowaniem bólu w okolicy kręgosłupa L-S $(p<0,001)$. Na dolegliwości bólowe skarżyło się 14
- 16\% dzieci (4 i 11osób) spędzających około 1 godziny dziennie przed komputerem czy telewizorem oraz prawie wszystkie przeznaczające na te czynności 4 i więcej godzin dziennie. 
Tab. 4. Czas spędzany przed komputerem a występowanie bólu kręgosłupa L-S $(p<0,001)$

Tab. 4. The amount of time spent daily on PC activities and the prevalence of LBP

\begin{tabular}{|c|c|c|c|c|c|c|c|}
\hline \multirow{2}{*}{ Liczba dzieci } & \multicolumn{6}{|c|}{ Czas spędzany przed komputerem } & \multirow{2}{*}{ ogółem } \\
\hline & $0 \mathrm{~h}$ & $1 \mathrm{~h}$ & $2 \mathrm{~h}$ & $3 \mathrm{~h}$ & $4 h$ & $>4 h$ & \\
\hline z bólem kręgosłupa L-S & $0(0 \%)$ & $11(16 \%)$ & $21(25 \%)$ & $14(58 \%)$ & $12(100 \%)$ & $10(100 \%)$ & 68 \\
\hline bez bólu kręgosłupa L-S & $7(100 \%)$ & $58(84 \%)$ & $64(75 \%)$ & $10(42 \%)$ & $0(0 \%)$ & $0(0 \%)$ & 139 \\
\hline ogółem & 7 & 69 & 85 & 24 & 12 & 10 & 207 \\
\hline
\end{tabular}

Tab. 5. Czas spędzany dziennie przed telewizorem a występowanie bólu L-S ( $p<0,001)$

Tab. 5. The amount of time spent daily on TV watching and the prevalence of LBP

\begin{tabular}{|c|c|c|c|c|c|}
\hline \multirow{2}{*}{ Liczba dzieci } & \multicolumn{4}{|c|}{ Czas spędzany przed telewizorem } & \multirow{2}{*}{ ogółem } \\
\cline { 2 - 6 } & $1 \mathrm{~h}$ & $2 \mathrm{~h}$ & $3 \mathrm{~h}$ & $4 \mathrm{~h}$ i więcej & 68 \\
\hline z bólem kręgosłupa L-S & $4(14 \%)$ & $16(22 \%)$ & $22(29 \%)$ & $26(90 \%)$ & 68 \\
\hline bez bólu kręgosłupa L-S & $25(86 \%)$ & $58(78 \%)$ & $53(71 \%)$ & $3(10 \%)$ & 207 \\
\hline ogółem & 29 & 74 & 75 & 29 & 239 \\
\hline
\end{tabular}

Częstsze występowanie bólu okolicy L-S zaobserwowano nie tylko w grupie dzieci stroniących od zajęć ruchowych, ale także wśród intensywnie uprawiających

sport w czasie wolnym od zajęć lekcyjnych (ponad 10 godzin tygodniowo).

Tab. 6. Czas przeznaczany na sport tygodniowo a występowanie bólu kręgosłupa L-S ( $p<0,001)$

Tab. 6. The amount of time scheduled weekly for sports activities and the prevalence of LBP

\begin{tabular}{|c|c|c|c|c|c|c|}
\hline \multirow{2}{*}{\begin{tabular}{c}
\multirow{2}{*}{ Liczba dzieci } \\
\cline { 2 - 7 }
\end{tabular}} & \multicolumn{5}{|c|}{ Czas tygodniowo przeznaczany na sport } & \multirow{2}{*}{ ogółem } \\
\cline { 2 - 7 } & $2-3 \mathrm{~h}$ & $4-5 \mathrm{~h}$ & $6-7 \mathrm{~h}$ & $8-9 \mathrm{~h}$ & $10 \mathrm{~h}$ i więcej & \\
\hline z bólem kręgosłupa L-S & $19(43 \%)$ & $19(22 \%)$ & $16(32 \%)$ & $3(21 \%)$ & $11(85 \%)$ & 68 \\
\hline bez bólu kręgosłupa L-S & $25(57 \%)$ & $67(78 \%)$ & $34(68 \%)$ & $11(79 \%)$ & $2(15 \%)$ & 139 \\
\hline ogółem & 44 & 86 & 50 & 14 & 13 & 207 \\
\hline
\end{tabular}

Dotyczy to nie tylko uczniów uprawiających intensywnie sport w czasie wolnym, ale także powstałych podczas pracy fizycznej. Około $35 \%$ dzieci (72 osoby) przyznaje, że musi wykonywać prace fizyczne po powrocie ze szkoły, $65 \%$ z nich (47 osób) uskarża się na bóle L-S. Dla 18\% (13 osób) praca ta wymaga dźwigania, z tej grupy $76 \%$ badanych zgłasza dolegliwości bólowe. Zależność między obciążeniem pracą fizyczną a występowaniem dolegliwości bólowych kręgosłupa L-S jest istotna statystycznie $(\mathrm{p}<0,001)$.

\section{Wpływ czynników psychicznych na występowanie bó- lów kręgosłupa L-S}

Dane uzyskane z kwestionariusza SDQ świadczą, że funkcjonowanie psychiczne większości ankietowanych dzieci (185 osób, 89,4\%) jest prawidłowe. Wyniki „na granicy normy" uzyskało 7,7\% dzieci (16 osób), poniżej normy 2,9\% dzieci (6 dzieci). Bóle tej okolicy stwierdzono u $29 \%$ dzieci bez żadnych problemów psychicznych, u 56\% z wynikami ,na granicy normy” oraz u wszystkich 
dzieci z zaburzeniami emocji, zachowania i komunikacji. Zaobserwowany związek częstości występowania bólu

L-S ze stanem psychicznym dzieci jest istotny statystycznie $(\mathrm{p}<0,001)$.

Tab. 7. Stan psychiczny dzieci a występowanie bólu kręgosłupa L-S $(\mathrm{p}<0,001)$

Tab. 7. Children psychological status and the prevalence of LBP

\begin{tabular}{|c|c|c|c|c|}
\hline \multirow{2}{*}{ Liczba dzieci } & \multicolumn{3}{|c|}{ Wynik testu SDQ-Pol } & \multirow{2}{*}{ ogółem } \\
\cline { 2 - 5 } & prawidłowy & na granicy normy & poniżej normy & \\
\hline z bólem kręgosłupa L-S & $53(29 \%)$ & $9(56 \%)$ & $6(100 \%)$ & 68 \\
\hline bez bólu kręgosłupa L-S & $132(71 \%)$ & $7(44 \%)$ & $0(0 \%)$ & 139 \\
\hline ogółem & 185 & 16 & 6 & 207 \\
\hline
\end{tabular}

\section{Dyskusja}

Bóle odcinka L-S kręgosłupa stanowią narastający problem wieku młodzieńczego. Po bólach głowy są to drugie w kolejności najczęściej odczuwane dolegliwości w tym wieku [15]. Dane epidemiologiczne dostępne w piśmiennictwie dotyczące ich występowania są jednak zróżnicowane. Zależą przede wszystkim od przyjętych założeń metodologicznych: czy ocenie podlegała częstość występowania bólu w odniesieniu do całego życia dziecka (ang. lifetime prevalence), czy w odniesieniu do zwykle niedługiego (np. jeden miesiąc) określonego odstępu czasu poprzedzającego badanie (ang. point prevalence). Ocenia się, że przed 17 rokiem życia większość uczniów w Europie (nawet 65,6 \%) doświadczyła bólu kręgosłupa L-S co najmniej jednokrotnie w swoim życiu, a u 5-19\% dzieci stanowi problem nawracający [15]. Występowanie bólów typu , point prevalence" u nastolatków waha się w krajach europejskich od $26 \%$ do $35 \%$ $[5,15,16]$. W krajach azjatyckich np. w Japonii odsetek ten jest mniejszy i wynosi odpowiednio $28,8 \%$,lifetime prevalence" oraz 10,2\%,,point prevalence" [17]. Podobne problemy występują w polskiej populacji. Bóle okolicy L-S o charakterze ,point prevalence” stwierdzono u 32,9\% badanych przez nas dzieci oraz wśród 39,4\% uczniów w wieku 10-13 lat z powiatu bialskiego, natomiast u dzieci starszych w wieku 13-16 lat odsetek ten sięga nawet $69,5 \%$. [18,19]. Obserwuje się wyraźną tendencję wzrostową tych dolegliwości wraz z wiekiem odczuwają je najczęściej trzynasto, czternastolatki i starsze [20,21]. W Europie północnej problem ten dotyczy około 4\% dzieci w wieku 9 lat, 11,6\% dzieci w wieku 11 lat, 22\% w wieku 13 lat, $36 \%$ młodzieży w wieku 15 lat [22]. Widoczny jest także trend wzrostowy w poszczególnych grupach wiekowych na przestrzeni lat. Metaanaliza badań obejmująca okres od lat 80-tych zeszłego wieku do 2011 roku wyraźnie pokazuje tę rosnącą tendencję, np. wzrost częstości występowania dolegliwości wśród 14-stolatków wzrosła z 30,3 \% do 43\% w przecią- gu 30 lat [23]. W polskim piśmiennictwie brakuje tak dokładnych danych, można porównać tylko uczniów wieku 10-13 lat z grupą wieku 13-16 lat, tendencja jednak jest podobna - im starsze dzieci, tym częściej skarżą się na dolegliwości bólowe L-S [18,19].

W niektórych doniesieniach zwraca się uwagę, że bóle okolicy L-S są na tyle dotkliwe, że stają się przyczyną ograniczeń codziennej aktywności i przyjmowania analgetyków [19,24]. Większość autorów jednak stwierdza zgodnie, że niewielu rodziców zgłasza się z tym problemem do lekarza. Dotyczy to również badanych przez nas dzieci. Może to wynikać z faktu, że dolegliwości te są zwykle krótkotrwałe, mają łagodne nasilenie, samoczynnie wygasają zazwyczaj przejściowo ograniczając sprawność dziecka.

Występowanie bólu kręgosłupa L-S nie jest najprawdopodobniej związane z płcią. Wprawdzie nieco częściej uskarżają się z tego powodu dziewczynki, nie wykazano jednak, niezależnie od wieku badanych, żadnej zależności statystycznej $[25,26]$. Podobny brak wpływu obserwuje się w przypadku wykształcenia i sytuacji materialnej rodziców, chociaż niektóre doniesienia wskazują na większe nasilenie dolegliwości w rodzinach o niskim poziomie zamożności. Wydaje się, natomiast, że miejsce zamieszkania dzieci ma związek z pojawianiem się bólu okolicy L-S. Czynnikiem sprawczym jest tu najprawdopodobniej obciążenie pracą fizyczną wśród uczniów mieszkających na wsi i wykonujących w czasie pozaszkolnym prace w gospodarstwie domowym, zwłaszcza wymagające dźwigania [27,28].

Związek występowania bólów kręgosłupa L-S z nadmiernym ciężarem teczek szkolnych nie jest do tej pory, mimo dość licznych badań, do końca jasno sprecyzowany. Wśród badanych przez nas dzieci ciężar szkolnego plecaka miał zasadniczy wpływ na występowanie dolegliwości bólowych. Aż 64,7\% nastolatków zgłaszających ból okolicy L-S nosiło plecak ważący osiem i więcej kilogramów. Podobne wyniki uzyskano badając duże populacje nastolatków w USA (1540 dzieci) w wieku 11-14 lat. 
Dolegliwości bólowe typu ,point prevalence” stwierdzono u $37 \%$ badanych, a ich nasilenie było wyraźnie związane ze wzrastającym ciężarem plecaka, a także utrudnieniem dostępności do osobistej szkolnej szafki, gdzie dziecko mogło zostawić część podręczników szkolnych, co z kolei mogłoby zapobiec niekorzystnemu przeciążeniu [24]. Być może stwierdzona przez nas silna zależność między ciężarem plecaka szkolnego a bólem kręgosłupa L-S wiąże się właśnie z bardzo niską w naszym kraju popularnością osobistych schowków na książki w szkołach. Inne duże badania populacyjne przeprowadzone w północnej Anglii (1046 dzieci) nie wykazały tak wyraźnego związku między mechanicznym obciążeniem kręgosłupa a ryzykiem wystąpienia epizodu bólowego okolicy L-S, większe znaczenie wydawał się mieć fakt współwystępowania bólu innych okolic ciała: brzucha, głowy czy gardła (ang. pain trajectory) [29].

Natomiast wśród doniesień oceniających wpływ codziennego stylu życia na występowanie bólów L-S w młodym wieku panuje przekonanie, że zarówno siedzący tryb życia jak i intensywne uprawianie sportu są znaczącymi czynnikami ryzyka wystąpienia tych dolegliwości [30]. Z naszych obserwacji wynika, że blisko $40 \%$ dzieci skarżących się na bóle okolicy L-S poświęca na oglądanie telewizji 4 i więcej godzin dziennie. Podobną ilość czasu, tyle że przed komputerem, spędza blisko jedna trzecia z nich. Podobne zależności stwierdzono oceniając sposoby wykorzystywania czasu wolnego przez dzieci w innych rejonach Polski oraz populacjach innych krajów [18,31]. Niestety tendencja do sedenteryjnego trybu życia wśród polskich nastolatków ma charakter narastający [32]. Prawdopodobnie brak wystarczającej aktywności fizycznej skutkuje niekorzystną przebudową tkanki łącznej podporowej ścięgien, więzadeł i mięśni polegającą na stopniowej utracie elastyczności i wytrzymałości na obciążenia, co z kolei powoduje ograniczony rozwój zdolności motorycznych i zwiększa narażenie na urazy narządu ruchu [33]. Z drugiej strony istotnym czynnikiem ryzyka dolegliwości kręgosłupa L-S jest wysoka aktywność fizyczna. Ponad $16 \%$ badanych przez nas dzieci z bólami tej okolicy poświęca na sport w czasie wolnym od zajęć szkolnych powyżej dziesięciu godzin tygodniowo. Wśród osób bez dolegliwości zaledwie 1,5\% uprawia sport z podobną intensywnością. W sporcie ryzyko związane $z$ bólem okolicy L-S zależy od typu uprawianej dyscypliny, a także intensywności treningu. Dolegliwości częściej występują przy intensywnym uprawianiu gimnastyki, piłki ręcznej, joggingu oraz tańca [30]. Są to dyscypliny sportowe, w których dochodzi do hypermobilności i przeciążania kręgosłupa. Sporty te nierzadko powodują ból ograniczający aktywność fizyczną, często także po zaprzestaniu ich uprawiania. Duże ryzyko występuje przy uprawianiu sportów walki, którym nierzadko towa- rzyszą urazy kręgosłupa [29,30]. Nie wykryto natomiast związku z regularnym, rekreacyjnym praktykowaniem sportu, który nie jest zbyt obciążający dla młodego organizmu. Systematyczna aktywność ruchowa ma wręcz znaczenie prewencyjne dla rozwoju wielu chorób cywilizacyjnych, w tym zespołów bólowych kręgosłupa [34,35]. Najbardziej korzystne jest pływanie, soccer, spacery i jazda na rowerze [36]. Trzeba jednak zwrócić uwagę, że nawet nadzorowana aktywność ruchowa o umiarkowanym nasileniu może przyczynić się do wystąpienia dolegliwości bólowych kręgosłupa. Według badań polskich nastolatków w wieku 13-16 lat ponad 23\% uczniów zgłasza pojawienie się lub nasilenie tych dolegliwości podczas lub bezpośrednio po zakończeniu lekcji wychowania fizycznego. Dzieje się tak prawdopodobnie $\mathrm{z}$ powodu niewłaściwego doboru ćwiczeń przez prowadzącego zajęcia [19].

W piśmiennictwie podkreśla się także duże znaczenie czynników psychicznych w powstawaniu bólów kręgosłupa L-S zarówno u dzieci jak u dorosłych. Wśród badanych przez nas uczniów wyraźnie widać, że im więcej trudności w kontrolowaniu emocji, im bardziej zaburzona komunikacja $\mathrm{z}$ rówieśnikami i gorsze funkcjonowanie społeczne tym częstsze występowanie dolegliwości bólowych. Istnieje wiele doniesień wskazujących, że nadmierny stres oraz labilny stan emocjonalny u młodych osób w znacznym stopniu współistnieją z bólem różnych okolic ciała, szczególnie kręgosłupa w części szyjnej i L-S [37,38]. Niektórzy autorzy zaobserwowali dwu, trzykrotny wzrost skarg z tego powodu u dzieci z problemami w codziennym funkcjonowaniu społecznym [39]. Niekorzystnie na stan psychiczny dziecka mogą wpływać kłopoty w kontaktach $\mathrm{z}$ rówieśnikami, zaburzenia zachowania, a także nadaktywność i zaburzenia koncentracji. Zwykle są to niepowodzenia w szkole oraz konflikty $\mathrm{w}$ rodzinie. Istotną rolę sprawczą spełniają nadmierne oczekiwania najbliższego otoczenia (rodzice, nauczyciele) mobilizujące do bardziej intensywnej pracy oraz uzyskania lepszych wyników w nauce i sporcie. Do tej pory nie rozstrzygnięto czy trudności psychiczne u dzieci są przyczyną czy skutkiem dolegliwości bólowych. Wiadomo jednak, że negatywistyczne, lękowo-depresyjne nastawienie do świata rzutuje niekorzystnie nie tylko na pojawienie się tego typu dolegliwości w wieku młodzieńczym, ale także na ich występowanie $\mathrm{z}$ tendencją do przewlekania się w wieku dorosłym [40].

\section{Wnioski}

1. Wśród czynników ryzyka bólów okolicy L-S w wieku młodzieńczym dominuje zarówno statyczne jak i dynamiczne przeciążenie kręgosłupa (nadmierny ciężar teczki szkolnej, siedzący tryb życia bądź intensywne uprawianie sportu, obciążenie pracą fi- 
zyczną) - wskazuje to na konieczność racjonalizacji stylu życia nastolatków.

2. Bóle okolicy L-S u nastolatków występują często, nie zaburzają jednak w istotny sposób ich funkcjonowania.

3. Istnieje związek między zaburzeniami emocjonalnymi a występowaniem bólu okolicy L-S u nastolatków. Wydaje się wskazane przeprowadzenie bardziej szczegółowej oceny wpływu stanu psychicznego uczniów na dolegliwości bólowe kręgosłupa L-S w celu opracowania ewentualnych działań profilaktycznych.

\section{Piśmiennictwo}

1. Dobosiewicz K. Niespecyficzny ból kręgosłupa u dzieci i młodzieży-uwarunkowania biomechaniczne, neurofizjologiczne oraz psychospołeczne. Neurologia Dziecięca 2006; 15(30): 65-68

2. Kiwerski J.E. Problem bólów krzyża u młodzieży. Postępy Rehabilitacji 2001; 15: 11-16

3. Woś H., Sobol G., Grzybowska-Chlebowczyk U. Bóle krzyża w schorzeniach wieku dziecięcego. Neurologia Dziecięca 2006; 15: 75-79.

4. Rostropowicz-Denisiewicz K, Romicka AM, Moskalewicz B. Dolegliwości ze strony układu ruchu wśród młodzieży ze szkół ponadpodstawowych. Reumatologia 2002; 40: 246-249.

5. Romicka AM, Rostropowicz-Denisiewicz K, Moskalewicz B, Wojtyniak B. Bóle spondylogenne u dzieci. Med Wieku Rozw 2003; 7: 165-172.

6. Lynch A., Kashikar- Zuck S., Jones B. Psychosocial risks for disability in children with chronic back pain. The journal of pain 2009, 7: 244-251.

7. Hestbaek L., Leboeuf-Yde C, Kyvik KO, Manniche C. The course of low back pain from adolescence to adulthood: eight-year follow-up of 9600 twins. Spine. 2006; 31(4):468-72

8. Salminen J.J. The adolescent bag. A field survey of 370 Finish school-children. Acta Paediatr. Scand. Suppl.1984, 315: $1-122$

9. Dunn KM, Jordan KP, Mancl L, Drangsholt MT, Le Resche L.: Trajectories of pain in adolescents: a prospective cohort study. Pain. 2011; 152(1):66-73

10. Goodman R (1997) The Strengths and Difficulties Questionnaire: A Research Note. Journal of Child Psychology and Psychiatry, 38, 581-586

11. Youthinmind Limited. 39A Welbeck Street London W1G 8DH.[cited 2011.08.12, last update 2013.07.15]. Available from: http://www.sdqinfo.org.

12. Mazur J., Tabak I., Kołoło H. W kierunku lepszej oceny zdrowia psychicznego dzieci i młodzieży. Polska wersja kwestionariusza mocnych stron i trudności: doświadczenia dwóch badań populacyjnych. Medycyna wieku rozwojowego 2007, 11(1):13-24
13. Mazur J., Tabak I. Narzędzia do badań przesiewowych w wykrywaniu zaburzeń zdrowia psychospołecznego dzieci i młodzieży. In: Wojnarowska B.,editor. Profilaktyka w pediatrii. Warszawa: PZWL; 2008.p. 549-552

14. Hendrickson AR, Massey PD, Cronan TP. On the test-retest reliability of perceived usefulness and perceived ease of use scales. MIS Quarterly 1993; 6:227

15. Calvo-Muńoz I, Gómez-Conesa A, Sánchez-Meca J. Prevalence of low back pain during childhood and adolescence: a systematic review. Rev Esp Salud Publica. 2012; 86(4):331-56 16.Lynch A., Kashikar- Zuck S., Jones B. Psychosocial risks for disability in children with chronicbackpain. Thejournalorpain2009;7:244-251

17. Sato T. Bone and joint diseases in children. Low back pain in children, Clin Calcium. 2010; 20(6):887-95

18. Kędra A., Czaprowski D: Częstość występowania bólu kręgosłupa a sposób spędzania czasu wolnego dzieci i młodzieży. Medycyna Ogólna i Nauki o Zdrowiu. 2013; (19),183-187

19. Kędra A., Czaprowski D.: Częstość występowania bólów kręgosłupa u uczniów powiatu bialskiego w wieku13-16 lat, Kwart. Ortop. 2012;(3),351-360

20 .Paprocka J., Jamroz E., Głuszkiewicz E., Klimczak A., Kluczewska E.,Marszał E: Zespoły bólowe kręgosłupa u dzieci, Wiadomości lekarskie.2008;(61),7-9

21. Lopez A., Mathers C., EzzatiM. Global and regional burden of disease a population health data. Lancet 2006; 367:1747-57

22. Kjaer P, Wedderkopp N, Korsholm L, Leboeuf-Yde C. Prevalence and tracking of back pain from childhood to adolescence. BMC Musculoskelet Disord.2011;12(1):98

23. Calvo-Muńoz I, Gómez-Conesa A, Sánchez-Meca J. Prevalence of low back pain in children and adolescents: meta-analysis. BMC Pediatr. 2013; 26:13-14

24. Skaggs DL, Early SD, D'Ambra P, Tolo VT, Kay RM.: Back pain and backpacks in school children. J Pediatr. Orthop. 2006; 26(3):358-63

25. Wedderkopp N, Leboeuf-Yde C, Andersen LB, Froberg $\mathrm{K}$, Hansen HS. Back pain reporting pattern in a Danish population-based sample of children and adolescents. Spine 2001; 26:1879-1883

26. Harreby MS et al. Risk factors for low back pain among 1.389 pupils in the 8 th and 9 th grade. An epidemiologic study. Ugeskr Laeger 2001; 63(3):282-6

27. Leboeuf-Yde C. Back pain--individual and genetic factors. J Electromyogr Kinesiol. 2004; 14(1):129-3

28. Hartvigsen J, Bakketeig LS, Leboeuf-Yde C, Engberg M, Lauritzen T. The association between physical workload and low back pain clouded by the "healthy worker" effect. Ugeskr Laeger. 2002; 164(21):2765-8

29. Jones GT, Waston KD, Silman AJ. Predictors of low back pain in British schoolchildren: a population-based prospective cohort study. Pediatrics 2003;111:822-8 
30. Sato $\mathrm{T}$ et al. Low back pain in childhood and adolescence: assessment of sports activities. Eur Spine J. 2011; 20(1):94-9

31. Turk Z, Vauhnik R, Micetić-Turk D. Prevalence of nonspecific low back pain in school children in north-eastern Slovenia. Coll Antropol. 2011;35(4):1031-5

32. Woynarowska B, Mazur J. Zachowania zdrowotne, zdrowie i postrzeganie szkoły przez młodzież w Polsce w 2002 r. Raport techniczny z badań. Wydz. Pedagog.UW. Warszawa; 2002 33.Kjaer M. Role of extracellular matrix in adaptation of tendon and skeletal muscle to mechanical loading. Physiol Rev. 2004; 84:649-698

34. Biliński P, Talkowski J, Szymkowiak E. Czy sportowa aktywność fizyczna chroni przed bólem kręgosłupa? Med. Sport. 1996; 63:13-16

35. Maszorek-Szymala A. Czas wolny dzieci i młodzieży teoretyczne rozważania w różnych aspektach Rocz Nauk WSWFiT Białymstoku 2010; 6:136-139
36. Skoffer B, Foldspang A. Physical activity and low-back pain in schoolchildren. Eur Spine J 2008;17(3):373-9

37. Mikkelsson M, Sourander A, Piha J, Salminen J. Psychiatric symptoms in preadolesc. with musculoskeletal pain and fibromyalgia. Pediatrics 1997; 100:220-27

38. Härmä AM, Kaltiala-Heino RK, Rimpelä M, Rantanen P. Are adolescents with frequent pain symptoms more depressed? Scand J Prim Health Care 2002; 20:92-96

39. Watson KD, Papageorgiou AC et al. Low back pain in schoolchildren: the role of mechanical and psychosocial factors. Arch Dis Child 2003; 88:12-17

40. Jones GT, Watson KD et al. Predictors of low back pain in British schoolchildren: a population-based prospective cohort study. Pediatrics 2003; 111:822-828 